\title{
GIFT THEORY AMONG GROUPS OF USERS OF CRACK AND OTHER DRUGS $^{1}$
}

\author{
Roberta Zaffalon Ferreira², Michele Mandagará de Oliveira³, Luciane Prado Kantorski, Valéria Cristina \\ Christello Coimbra ${ }^{5}$, Vanda Maria da Rosa Jardim ${ }^{6}$
}

\footnotetext{
${ }^{1}$ Article extracted from the dissertation 'The anthropological meaning of gifts among groups of users of crack and other drugs', presented to the Postgraduate Program of the Faculty of Nursing of the Universidade Federal de Pelotas (UFPel), in 2013.

${ }^{2}$ Doctoral student of the Postgraduate Program of the Faculty of Nursing, UFPel. Pelotas, Rio Grande do Sul, Brazil. Email: betazaffa@gmail.com

${ }^{3}$ Ph.D. in Nursing in Public Health. Adjunct Professor of the Faculty of Nursing, UFPel. Pelotas, Rio Grande do Sul, Brazil. Email: mandagara@hotmail.com

${ }^{4}$ Ph.D. in Nursing. Adjunct Professor of the Faculty of Nursing, UFPel. Pelotas, Rio Grande do Sul, Brazil. Email: kantorski@ uol.com.br

${ }^{5}$ Ph.D. in Nursing. Adjunct Professor of the Faculty of Nursing, UFPel. Pelotas, Rio Grande do Sul, Brazil. Email: valeriacoimbra@ hotmail.com

${ }^{6}$ Ph.D. in Nursing. Adjunct Professor of the Faculty of Nursing, UFPel. Pelotas, Rio Grande do Sul, Brazil. Email: vandamjardim@ gmail.com
}

\begin{abstract}
This is an excerpt from a dissertation which sought to investigate the meaning of gift theory among groups of users of crack and of other drugs within the scenarios of use. The study has an ethnographic approach; participants were 13 persons who made use of crack and other drugs in the scenarios of use in the Municipality of Pelotas in the state of Rio Grande do Sul, and the observations were made in 2013. The results evidenced that the users are victims of prejudice, but maintain the gift in their relationships and seek to help each other and show solidarity as a group. It was possible to share and demystify a highly specific and invisible way of life of the crack users; however, the changes will only begin to appear when more efficacious means of approach are found, with health policies for promoting closeness and links with this population, providing, above all, embracement of their needs, which at many times appeared to be neglected.
\end{abstract}

DESCRIPTORS: Crack cocaine. Drug users. Cultural anthropology.

\section{A TEORIA DOS DONS E DÁDIVAS ENTRE GRUPOS DE USUÁRIOS DE CRACK E OUTRAS DROGAS}

RESUMO: Trata-se de um recorte de dissertação que buscou conhecer o sentido da teoria dos dons e dádivas entre grupos de usuários de crack e outras drogas dentro das cenas de uso. O estudo possui abordagem etnográfica; os participantes foram 13 pessoas que faziam uso de crack ou outras drogas nos cenários de uso no Município de Pelotas-RS e as observações se realizaram no ano de 2013. Os resultados evidenciaram que os usuários são vítimas de preconceito, mas mantêm o dom em suas relações e buscam se ajudar e serem solidários como grupo. Foi possível compartilhar e desmistificar um modo de vida muito particular e invisível dos usuários de crack, no entanto, as mudanças só começarão a aparecer quando se produzirem meios de abordagem mais eficazes, com políticas de saúde para promover a aproximação e vínculo com esta população, proporcionando, sobretudo, acolhimento de suas necessidades, que em muitos momentos apareceram negligenciadas.

DESCRITORES: Cocaína crack. Usuários de drogas. Antropologia cultural.

\section{TEORÍA DEL DON Y DONACIÓN ENTRE LOS GRUPOS DE USUARIOS DE CRACK Y OTRAS DROGAS}

\begin{abstract}
RESUMEN: Es un recorte de disertación que buscó conocer el sentido de la teoría de los regalos y donaciones entre grupos de usuarios de crack y otras drogas dentro de cenas de uso. Tiene abordaje etnográfico y ocurrió con 13 personas que usaban crack u otras drogas en los escenarios de uso en Pelotas-RS. Las observaciones fueron realizadas en el año de 2013. Los resultados evidenciaran que los usuarios son víctimas de preconcepto, pero mantienen el don en sus relaciones, y buscan se ayudaren y ser solidarios mientras grupo. Fue posible la cuota y desmitificación del modo de vida, que es muy particular e invisible de los usuarios de crack. Sin embargo, los cambios empezarán a aparecer cuando de producir medios de abordaje más eficaces con políticas públicas de salud para promover la aproximación y vínculo con esta población, proporcionando acogimiento de sus necesidades, que en muchos casos aparecieran descuidadas.
\end{abstract}

DESCRIPTORES: Cocaína crack. Consumidores de drogas. Antropología cultural. 


\section{INTRODUCTION}

Human beings have always lived in search of something which transcends the dimension of what is real, as various types of culture have developed socially accepted forms of using psychoactive substances, without exposing life to risks and even, on many occasions, being divinized, there being records of this practice being common since prehistory for recreational, curative and religious purposes. $^{1}$

One of the explanations which reveal the reason why, for a long time, drug use was accepted peacefully among people is that this practice did not represent any greater threat to society and was concentrated in the nucleus of collective rituals which society recognized as an expression of its own values. ${ }^{2}$

Crack (a drug based on cocaine paste) is a typical example of a psychoactive substance which possesses notorious characteristics which "threaten" society, and is involved in a series of doubts regarding the understanding of this phenomenon. ${ }^{3}$

Since it arrived in Brazil, with the first reports of its use occurring in São Paulo, in the state of São Paulo (SP) in the middle of the 1980s, to its popularization, crack has occupied increasing space in the media, in society in general, and in public policies, of both health and security. In the media it is treated as an "epidemic", representing the idea of its spread as a public health problem, and in the social context. ${ }^{4}$

To be a crack addict can be an intense and difficult choice for these people, who are commonly stigmatized and indicated as being worthless and not deserving to partake in social coexistence. For most of society, using crack is a repugnant act and the tendency is for prejudice to become visible in relation to these addicts. ${ }^{5}$

It is possible that, in the light of this context which demonstrates the prejudice experienced by these people, people should understand better the common act of consuming the drug in a group, as this has been a common practice since the emergence of crack in the United States of America, where the drug was produced in a homemade way and consumed in groups, inside houses of varying degrees of abandonment and delapidation (known as crack houses). ${ }^{6}$ These relationships, and the coexistence which occur in groups may be better understood through the construction of a social bond, one of the most striking characteristics of gift theory, in which bonds exceed the market value or contract normally imposed within society. ${ }^{7}$

The studies existing on this issue, in the most part, seek to outline the profile of the drug addicts, the epidemiological data, and the harm caused by the drug's consumption. In the context of the space where the drug is used, and the creation of 'crack-lands', studies are being undertaken on a large scale; however, the focus is nearly always directed towards the areas in which drugs are available or used, to the use of crack in association with other drugs, the history of starting to use crack, and the experiences of being a crack user, there being a gap in the specific attention to the human being who has experienced all these experiences mentioned. ${ }^{4-5,8-9}$

Studies in the socio-cultural and anthropological ambit regarding the use of crack seek to describe this life context and the typical behaviors of those who consume it, anthropology being an important tool for in-depth investigation of the social phenomena linked to people who use drugs. ${ }^{10}$

In this aspect, I emphasize the rationale for this study, which is to understand the meaning of gift theory within this group of people, to give them an active voice, and to value their life stories, as human beings who belong to society which possesses a range of cultures and different forms of lifestyle. Crack, in spite of the harm which it causes, continues to attract people to the habit of consuming it. As a result of this, one can see the importance of developing public policies for care and prevention against the use of drugs, based in these people's context and experience, increasing the possibilities of caring for the subject as a whole.

In the light of the above, the following investigative question arose: What is the meaning of gift theory among groups of users of crack and other drugs within the scenarios of use? It aims to investigate the meaning of gift theory among groups of users of crack and other drugs within the scenarios of use.

\section{THEORETICAL FRAMEWORK}

The data collected through participant observation and dialogue, recorded appropriately in a field diary, were analyzed and discussed in the

A literal translation of the Portuguese word 'cracolândia', which describes an area or neighborhood characterized by the high number of crack addicts visiting to buy or use the drug. Translator's note. 
light of Gift Theory, and also based in the work of authors who are members of the Antiutilitarian Movement in the Social Sciences.

Gift Theory has a critical position against the economic view of the world. The theorist who laid the foundation for this theory criticizes the image of homo oeconomicus which is imposed increasingly strongly, both in the social sciences and in the life of societies. These criticisms are based in the discoveries made by him in the savage or traditional societies, or those termed by him as "first societies". In these societies, the relations of exchange occur in the light of what is termed the triple obligation model (giving, receiving and reciprocating), contrary to the market model of "take this, give that here" which is in place up to the present time. ${ }^{11}$

Through Gift Theory, it is sought to explain the system of exchange and the constitution of alliances in human relationships; this being the case, one of the main contributions for sociology was to demonstrate that the value of the things cannot be superior to the value of the relations. ${ }^{12}$

The exchange system, termed potlatch, relates to the "total services of an agonistic type", that is, that provokes rivalry and competition, between people, families or clans. This practice was common among the Native Americans of the Northwest coast of North America, where chiefs offered their goods, competing amongst themselves to see who could offer the greatest quantity of goods (generally sculpted ornamental 'coppers' and animal skins), and who was the most generous. ${ }^{13}$

There was also what was called kula, another form of intra-tribal exchange, with circular exchanges of useful goods (bracelets and necklaces) between different Melanesian islands. The theoretician explains kula as being the potlatch of the Trobriand population and it was seen by him as the best example of giving. In Polynesia (in Samoa), on the other hand, the contractual systems involved events such as marriage, the birth of children, circumcision, girls' puberty, commerce and funeral rites. ${ }^{12-13}$

It was concluded that, in reality, no society was based on barter, but that, rather, objects circulated supported by principles which were opposed to economic principles, circulating in the form of gifts, there being manifestations of generosity, and being distanced from the exact act of calculating (receiving the same that one gave). ${ }^{11}$

\section{METHODOLOGY}

The present study is an excerpt from a dissertation linked to the project titled "Profile of crack users and patterns of use in the city of Pelotas-RS". This study is qualitative, and was undertaken in accordance with the ethnographic perspective.

The fundamental purpose of the investigation of the ethnographic type is cultural description, essentially made possible by participant observation of activities undertaken by the members of a specific group over a long period of time. ${ }^{14} \mathrm{As}$ a result, the present study used the techniques of participant observation and dialogue with persons who were using crack and other drugs, all data later being recorded in a digitalized field diary.

Data collection took place in the Municipality of Pelotas-RS, Brazil, with the help of staff from the Harm Reduction Strategy (ERD). The starting point was direct observation, progressing to participant observation, whenever the field conditions permitted. The observations were made in urban, public and private environments, in which people made use of crack and other drugs. The period of observation covered eight consecutive months, from January to August 2013, with approximately 90 days and 360 hours of observation.

The study participants were people who made use of crack or other drugs in the scenarios of use of drugs (open, public or private) and who accepted that observation should be undertaken. A total of 13 participants were continuously monitored, selected based on the inclusion criteria: to be over 18 years old and to be making use of some illicit drug at the time of the observation; when the observation took place in a private environment, the ethnography began with the person living in the house selected as the scene of use.

The analysis of the data obtained is presented based in interpretivism. ${ }^{15}$ Interpretivism is described as an analysis which penetrates the body of the study object, that is, it begins with the interpretations of the researcher regarding the intentions of the informants or research subjects, or what the researcher believes that they intend, subsequently systematizing these ideas and interpretations. ${ }^{15}$

The "Profile of crack users and patterns of use" project was referred to the Committee for Ethics in Research in the Area of Nursing, of the Universidade Federal de Pelotas (UFPel), and was approved under Opinion n. 301/2011. The terms of consent were handed to the study subjects, pre- 
senting the study's objective, and guaranteeing anonymity in relation to the information provided by them, free access to the data and results achieved, as well as answers to any questions or doubts and the right to withdraw from the investigation at any time. All the subjects were identified with fictitious names, as were the places observed, respecting the ethical precepts of Resolution 196/96. ${ }^{16}$

\section{RESULTS AND DISCUSSION}

The groups observed had high turnover in terms of their members. On most occasions, it was not possible to count the number due to the high rotation of persons, however, over time, contact was established with some persons due to the creation of a closer alliance and bond, which made it possible to know them more intensely.

Of the women, those present most were Valesca (27 years old), Sandra (28 years old), Nara (44 years old) and Daniela (31 years old), who presented similar characteristics. They were cheerful, extroverted, charismatic and communicative, always ready to tell eccentric stories and contribute to the study. There was also Bela (36 years old), who was a woman with sad features, depressed and introverted.

Among the women, one was always accompanied, but appeared distant and cold -Bárbara (30 years old). At various times she was withdrawn and aggressive, but on the occasions when it was possible to get close to her, life stories, both happy and sad, were revealed. Nara (25 years old) and Adriana (30 years old) were unobtrusive people, with a suffering appearance and limited receptiveness, demonstrating on various occasions an absence of openness or flexibility for dialogue.

Of the men, with Josué (30 years old), Zilmar (31 years old) and Jerônimo (18 years old) there was intense closeness during the entire field period. Rubens (60 years old) and João (25 years old), on the other hand, were more introspective people, who communicated with difficulty, but who were willing to contribute to the study, sharing their stories.

Thus, the scenes of use of crack and other drugs are made up of people with widely varying personalities and feelings, who co-exist, sharing the space and creating groups which varied in accordance with the people who were present.
The most intense observations took place in four locales of the city, one being a private residence (Pedro's house), and the others, public spaces (Rua da Cidadania, the 'Beco' and the Recanto da Saudade cemetery), all situated in different neighborhoods on the outskirts of the city ${ }^{* *}$. Although the places were geographically distant from each other, all had something in common: poverty, the intense presence of garbage, a lack of basic sanitation, and unreliable or absent electricity. The ethnography was concentrated in these environments, due to the ease of finding groups made up of people making use of crack and other psychoactive substances.

The literature shows that the places observed where crack is used can occur in a wide variety of spaces, taking place in isolation or collectively. These spaces may be a person's own home or the house of friends or relatives, which undermines the ideas that 'crack-lands' are found only in public spaces and central areas, as indicated by the mainstream media. ${ }^{17}$

The crack users, based on their lifestyles, may be breaking with the relationships imposed by capitalist society; however, by contrast, they establish experiences created in favor of interests related to crack. They come to incorporate other interests, such as the various ways of managing to find the money to buy the crack, involvement in debts, and informal work, among others, which surround their relationships. ${ }^{11}$ In these groups, the existence of capitalist and non-commercial exchanges is clear, there being no single model of exchange between them. The types of relationship support their interests in accordance with the period through which they are living. In general society, relationships of commercial exchange are predominant, exchanges being based on capital, with money being the mediator of the relationships. However, there are other relationships of exchange, shown through studies with primitive peoples, indicating types based on giving/ receiving/reciprocating, which are not based on the value of the goods. ${ }^{13}$ In the scenes of drug use, there are also events/relationships which do not fit into the commercial/capitalist relationships; rather, they are exchanges and alliances, such as the shelter offered in these places to those who are homeless, the friendship, the collective help against the adversities met on the streets, and the sharing of the drug itself, besides food and clothes.

Housing for the poor tends to be found on the outskirts of Brazilian cities, rather than in inner-city areas. Translator's note. 
The places where this population chooses to live end up being transformed into what are popularly known as 'crack-lands'. There is, however, an idea that this locale is purely for consuming drugs, which for some it indeed is, but for others, it ends up being the only place they can live.

As a result, the crack-lands take on different scenarios, according to the needs of each person. The majority make use of this locale for consuming drugs, in company with the others who frequent it. It is also a place which others pass through, as many walk around the entire city alone, and, in these environments, can re-encounter their acquaintances and friendships from time to time; and it is a place to stay, for those who have nowhere to stay or live, people who are taken there by acquaintances as a form of shelter, as they have no house or safe place to spend the night - or even days. There are also those who visit the area only to accompany their boy- or girlfriends or friends; it is also a place of protection from police officers and enemies. That is to say, the crack-lands are places, above all, of human relationships and exchanges, whether commercial or not, which keep the people in these spaces in order to satisfy their needs.

In the light of the need of each person who frequents these different scenarios of use, one might think that, in these environments, no matter how hostile and insalubrious they may be in some peoples' eyes, there are relationships guided by drug use, but there is also solidarity among them, protection and company, among others. These are places for material and non-material exchanges, and for relationships between individuals who support the group in these spaces. The paradigm of the gift tries to explain these relationships, and seeks to explain the system of exchange and the constitution of alliances in the human relationships, and demonstrates that the value of the things cannot be superior to the value of the relationships, in which, above all, symbolism is fundamental, permeating these relationships. ${ }^{12}$

The groups observed were made up of various people, men and women, who preferred to organize themselves into small groups, forming twos or threes, so as to share in the consumption of psychoactive substances in this way.

The Rua da Cidadania - more specifically, the Wall - is the space where people get together to consume drugs. By this wall there were six people [three men and three women]. One of the women was, at the most, 18 years old, and was using crack with a man. They were organized in pairs, two men were smoking tobacco and marijuana, and sharing the roll-ups; they were sitting very close, one in front of the other, and were talking a lot when we arrived. Two women were hidden behind a piece of wood which they had placed against the wall, simulating a shelter, a hut, but very close to the wall, which made it very difficult to see them (Field Diary).

Daniela, one of the participants, referred to the group as a family in which everybody helped everybody else, sharing things between themselves, but in which everybody was good. If somebody did something which was not good, he or she was promptly excluded from the group, although she noted that everybody there had done crazy things for the drug at some point, but that it was no longer permitted to rob, kill or any other thing which threatened anybody. Everybody in that group knew somebody who had killed, men who had anal sex in exchange for the drug, and women who had sex for money.

In these former experiences of the group, as reported by Daniela, the paradigm of individualism overcame the paradigm of the gift, as the interested search for something is shown to be merely for one's own satisfaction, alliance and social bond not being prevalent in these actions.

Besides the family atmosphere in these groups, as mentioned by Daniela, through the insertion of the researcher in this environment, it was possible to observe that the ritual which they possess of drug use was very similar to the ritual undertaken by many people who enjoy getting together in a group to drink chimarrão. On most occasions there was only one pipe for the entire group, and somebody was responsible for preparing it and passing it around the group in a circular movement. The 'rocks' of crack were provided by whoever had them at that moment; the people who did not provide the drug at that particular time were not excluded from its use. When they had it, they shared it with the group. Voluntarily and spontaneously, the people made themselves ready to go and get money or more crack when they noticed that it was nearly gone.

The rituals may be understood as events present in contemporary life, whether these are sacred or mundane, banale (such as routine greetings) or religious, political and civic ceremonies, that is, events which construct and express life, both individual and social. ${ }^{18}$ As a result, smoking crack in the group becomes a rite which strongly characterizes some of the activities which most represent the group. 
However, in this scenario of the "group/ circle of chimarrão", Gift Theory can explain the intrinsic value existing in this relationship. The alliance and the bond created between these people is what supports the trust and the relationship of solidarity, such that the person who today does not have any crack may enjoy the smoke equally with the person who provides the crack in the circle, in the guarantee and certainty provided to the group that, as soon as he has some crack, it will be shared in the same way with those who are sharing it with him. Discussing the concepts of gift theory in greater depth, this action may be justified by the strength which exists in the thing which is given/donated (hau), in that everything which is given always tends to return to the giver in the form of the good itself or something similar, which substitutes it. ${ }^{13}$

Another member of the group, from the Beco, was questioned about the existence of good things in living in this way that had been chosen. Adriana answered emphatically: I love using crack, I really like it, I know and understand all the evils which it causes to me socially. I end up staying here, with this group, in order to use my drug, and I like rum as well, I'm addicted. When I use crack I need to use rum too, as this strengthens the action of the crack, and I become extremely changed, I cry and I get aggressive, cursing everybody, and what is best is that they understand and put up with me (Adriana).

The fact of liking being part of these groups, of being on the street with the other users and sometimes referring to them as a family can be explained based on the coexistence which they have or had with their family members in their homes. The family is considered an institution which normatizes, legalizes and legitimates the behaviors of the individual in society. As a result, the family nucleus creates rules and practices of behavior and thought which are permitted or not to the individual belonging to that family. ${ }^{19}$ The crack users often end up breaking with these imposed rules, due to the fact that consuming crack is a behavior and practice repressed within the family. Hence, they choose to weaken or break the family bonds, and live on the streets in such a way as to create their own norms and rules.

The act of collecting garbage, for some of them, signifies an issue of survival on the streets. On the Rua da Cidadania, over time, one can perceive and follow the construction of "huts", built against the wall as a form of shelter, housing and protection. These hovels were constructed only out of garbage or materials found on the street. Within a month, there were about five such huts, and it was possible to follow the evolution of the constructions, which took place very fast each week.

Nara, in one of her conversations, explained that she always paid attention to the garbage, as it was from there that she had found many good things to build her hut, there being little time to lose, as winter was coming and the cold punished those who lived on the streets. Nara was always accompanied by her boyfriend, who helped her in this laborious task.

Thus, the work undertaken in a group by these people, in order to construct a place of shelter is clear, and this was both undertaken, and made later use of, together. On a number of nights it was possible to observe the people using crack in these huts, more provately and in small groups, in accordance with the size of the space inside.

In the cemetery too, the researchers witnessed scenes of adaptation and means of protection as a group in preparation for the arrival of the winter. Sofas, mattresses and blankets were found in various of the visits, as well as the creation of a curtain tied with ropes for protection against the wind, and sheets of cardboard simulating improvised walls.

It was noted that there was a form of adaptation and care within this population, mainly in relation to changes in the weather, as the winter is very rigorous in this region. Among them, there is an attempt to keep the group comfortable, within what is possible, and the need for some to care for the others.

Regarding this group as an organization, in almost all the scenes, the strong presence of a leader was striking. It was the leader who, besides keeping the group organized and in order, decided issues referent to the preparation of the crack and the consumption of the drug. In some groups, the leader was the person responsible for preparing the pipe and for establishing the order in which the crack was consumed, it falling to the other members to obey the orders and wait their turn to "have a drag".

In the midst of this scenario, it was possible to perceive that the leader also shared her drugs, although most was given by members of the group, who shared their crack with everybody present in the circle. The strength of the thing which was given, which tends always to return to its giver (hau) was very clear in this ritual, as, following the giving of the crack by the leader of the group, more crack tended to return to him, 
completing the circle of giving, receiving and reciprocating, fed by the relationship of alliance and solidarity in the group, characterizing the intrinsic obligatoriness in the act of giving, receiving and reciprocating. ${ }^{13}$

Daniela, the girlfriend of the owner of one of the private houses where consumption took place, showed herself to be the natural leader of the group, due to her firm stance and to being considered one of the owners of the house:

[...] In the center of this group, and here I refer to the center as the leadership of the group, was Daniela. When I arrived she was in command of the preparation of the crack in pipes to be smoked. It was she who prepared it for everybody in the group. She had a plate on her lap with a lit candle, a piece of card which served as a spoon, the pipe and the rocks [...]. While we conversed, everybody sat on the ground [including me and the ERD] in a circle, she prepared pipes all the time and smoked when her turn came around [...]. One man, the oldest in the group, who lived on the street, was restless, wanting to take a drag. She swore at him, said that his turn was coming, and that he knew how to wait. He promptly obeyed her. After smoking, he went to the streets in search of money, in order to get more of the drug and return to smoke in the group (Field diary).

However, the leadership, although strong in some groups, is not present in all of them. In its absence, the users organize among themselves the ritual of preparing the pipe, such that all may be encompassed in the act of smoking. Very often, the work is undertaken as a team, in which each one performs a task, such that the pipe may be well prepared without overloading anybody.

When we approached a group on the Rua da Cidadania, I understood why they were and with their heads bowed. All had pipes in their hand, and, as they held them, seemed to be in trances with those objects. One of them was scraping $a$ can and the others were collecting the ashes and prepared the fire in order to light the rock (Field diary).

Corroborating other works, the means of using crack found in this study also involved smoking out of pipes and cans, as reported in studies undertaken in the state of São Paulo and in the United States. The pipes may be made of wood, but may also be put together by hand by the users, with materials rescued from garbage mainly being used, such as the tops of plastic bottles, antennas, pens, aluminum cans (beer and soft drinks) and cigarette lighters among others, also having tobacco ash as an essential element in order to be lit. ${ }^{8,17}$
Besides this exchange and mutual help in the preparation of pipes in order to smoke, found in all the groups of people who use crack, there is also another relationship of exchange and solidarity among them. There is great concern among them referent to the health of the other. There is concern with those who are pregnant and who do not undertake prenatal consultations, and people with health problems such as tuberculosis and other needs and weaknesses, to which the users are exposed as a result of their use of crack and other drugs.

The gift, it may be noted, is something which permeates the relationship among these people, and, in this case, occurs in such a way as to establish bonds of help, warmth and solidarity. ${ }^{11}$

One of the young women present in the group in Pedro's house where the drug was consumed, in addition to being a compulsive user, had a mental deficiency - and after smoking four consecutive rocks did not fully know what she was doing, as she was trying to light a pipe and could not. At that moment, another young woman who was smoking with her helped her kindly, asked her to remain calm and lit the fire, burned the rock and told her to breathe in at the right moment. I perceived a gentleness in this act, as, faced with the weakness of her friend, she showed solidarity (Field diary).

The group from the cemetery showed itself to be a group which welcomed people from outside, who were without shelter. In the three visits, the researchers witnessed that men from other localities who were passing through the city were welcomed in that environment to pass the night there and make use of the group's drugs.

In one ethnographic study undertaken in São Paulo, this welcoming characteristic was shown similarly; two people reported finding company in the group which they did not have outside this environment. They were people who were alone, with no family members, and apparently with few perspectives for the future. In one of the cases, the subject was ill, unable to work or smoke (the drug), and refusing to receive help with health, alleging that he felt better close to "his own", even though he could not smoke, purely for the companionship and the "atmosphere". ${ }^{20}$

There is also the solidarity of the people who have their own homes, in that they offer this space to those without shelter who have nowhere to smoke and who do not wish to expose themselves on the street. Such scenes were witnessed in the houses of Pedro and of Marina, and, some months 
ago, in the house of Sandra, which was also a house where the drug was consumed. The houses' owners offered them and left the doors open to whoever wanted to smoke or needed shelter, thus transforming them into true aglomerations of people, and forming the crack-lands in private and more unobtrusive places.

On the Rua da Cidadania there is greater circulation of people who are addicted to crack and living on the street, and, as a result of this, there is a greater number of people with bigger weaknesses and health problems. Throughout the undertaking of the study, the action of people with better health requesting help for those who were debilitated was common.

This health guidance, requested by the users themselves, demonstrates the notion that they have regarding the risks of transmitted diseases - due to the use of the shared pipe - to which they are subject. The heated metal causes lesions on the cutaneous tissue, leading to the appearance of blisters on the tongue, lips, face and fingers. As the pipe is shared, the contact with the blood of other users can increase the risk of transmission of infectious diseases. Among the female population, the harm can be even greater, given that some users reported the practice of exchanging sex for crack, which, when undertaken without protection, increases the risks of infection by sexually-transmitted diseases, including HIV. ${ }^{17,21}$

\section{FINAL CONSIDERATIONS}

Through undertaking the study, it was possible to share and demystify the highly specific and invisible lifestyle of users of crack and other drugs with the wider population. Without intending to generalize, it was sought to value the uniqueness of each person monitored closely, and the organization as a group, showing the different exchanges and alliances constituted.

Throughout this path and time of observation, it was observed that, in different situations, the relationships of the exchange/gift are what maintains the group as a group. The group takes on a welcoming role in the absence of family- or friendship-based bonds and, in these locales of use, people feel that they are in conditions of equality, and far from recrimination and judgment.

The search for interests, within the parallel society created by them, is also clear. At the same time that they seek to cut themselves loose from capitalist society, from the morality and rules which rule our society, they organize themselves in a particular way, encapsulated in a group which creates its own rules, norms and morality. They seek their interests, becoming involved in a strong capitalism ruled by the illegal sale of drugs, financial agreements between pusher and user, illegal activities, and hence achieve their objectives.

However, in the light of so many striking findings, of lives of suffering and others which are less so, of help, of solidarity and also of interests, respecting the human being and trying to understand different ways of living may perhaps be major challenges to overcome in the struggle against the prejudice and stigma created regarding drug users.

Changes will only begin to appear in these peoples' context when the policies for care and assistance involving this population come to be prioritized by managers. For this, it is necessary to value studies of the social and cultural context of scenarios of drug use, in a way which is integrated with epidemiological and statistical data, with the aim of understanding the phenomenon of drug use, facilitating the immersion of different actors in this context, and bringing different areas of knowledge closer, such that they may produce more efficient means of approach, closeness and bond with this population, allowing, above all, the embracement of their needs, which at many times appear to be neglected.

As limitations of this study, one may point to the difficulty of traveling to the places observed, as the ERD service did not have its own vehicle for transporting the health workers and researchers, it being necessary on various occasions to use public or private transport, requiring more time and greater expense in travelling. Furthermore, the high turnover of users in the scenes of use made it impossible to maintain continuous contact with them, more intense closeness being possible with only 13 persons over the eight months of fieldwork. As a suggestion for future works, emphasis is placed on the importance of the inter- and multidisciplinary work, in particular developing a closer relationship with the harm reduction staff, who were the main gateway, and who were responsible for developing a bond with this population, as the users, due to feeling welcomed and assisted, through this relationship of trust, made possible the intervention of other professionals. 


\section{REFERENCES}

1. Raupp LM. Circuitos de uso de crack nas cidades de São Paulo e Porto Alegre: cotidiano, práticas e cuidado [tese]. São Paulo (SP): Universidade de São Paulo. Faculdade de Saúde Pública; 2011.

2. Filho AN, MacRae E, Tavares LA, Rego M. Toxicomanias: incidências clínicas e socioantropológicas [online]. Salvador (BA): Centro de Estudos e Terapia do Abuso de Drogas, Editora UFBA; 2009; [acesso 2013 Nov 01]. Disponível em: https:/ / repositorio.ufba.br/ ri/bitstream/ufba/183/1/Toxicomanias.pdf

3. Perrenoud LO, Ribeiro M. Histórico do consumo de crack no Brasil e no mundo. In: Ribeiro M, Laranjeira $\mathrm{R}$, organizadores. O tratamento do usuário de crack. Porto Alegre (RS): Artmed; 2012. p.33-8.

4. Melotto P. Trajetórias e usos de crack: estudo antropológico sobre trajetórias de usuários de crack no contexto de bairros populares de São LeopoldoRS [dissertação]. Porto Alegre (RS): Universidade Federal do Rio Grande do Sul, Instituto de Filosofia e Ciências Humanas; 2009.

5. Almeida RBF. O caminho das pedras: conhecendo melhor os usuários de crack do município de RecifePE [dissertação]. Recife (PE): Universidade Católica de Pernambuco; 2010.

6. Alves HNP, Ribeiro M, Castro DS. Cocaína e crack. In: Diehl A, Cordeiro DC, Laranjeira R. Dependência química: prevenção, tratamento e políticas públicas. Porto Alegre (RS): Artmed; 2011. p.170-9.

7. Caillé A. Antropologia do dom: o terceiro paradigma. Petrópolis (RJ): Vozes; 2002.

8. Oliveira LG, Nappo AS. Crack na cidade de São Paulo: acessibilidade, estratégias de mercado e formas de uso. Rev Psiquiatr Clin. 2008; 35(6):212-8.

9. Oliveira LG, Nappo AS. Caracterização da cultura de crack na cidade de São Paulo: padrão de uso controlado. Rev Saúde Pública. 2008; 42(4):664-71.

10. Ribeiro LA, Nappo SA, Sanchez ZVDM. Aspectos socioculturais do consumo de crack. In: Ribeiro M, Laranjeira R, organizadores. O tratamento do usuário de crack. Porto Alegre (RS): Artmed; 2012. p.50-6.
11. Caillé A, Graeber D. In: Martins PH. A dádiva entre os modernos: discussão sobre os fundamentos e as regras do social. Petrópolis (RJ): Vozes; 2002. p.17-31.

12. Martins PH. A sociologia de Marcel Mauss: dádiva simbolismo e associação. Rev Crít de Ciênc Soc. 2005; (73):45-66.

13. Mauss M. Sociologia e antropologia. São Paulo (SP): Cosac Naify; 2003.

14. Neves T. A etnografia no estudo do desvio. In: Anais do V Congresso Português de Sociologia - Sociedades Contemporâneas - Reflexividade e Acção, 2006; Portugal. p.96-101.

15. Geertz C. A interpretação das culturas. Rio de Janeiro (RJ): LTC; 2008.

16. Ministério da Saúde (BR). Conselho Nacional de Saúde. Diretrizes e normas regulamentadoras de pesquisa envolvendo seres humanos. Resolução $\mathrm{n}$. 196, de 10 de outubro de 1996. Brasília; 1996.

17. Jorge MSB, Quinderé PHD, Yasui S, Albuquerque RA. Ritual de consumo do crack: aspectos socioantropológicos e repercussões para a saúde dos usuários. Rev Ciênc Saúde Colet. 2013; 18(10):290918.

18. Langdon EJ. Rito como conceito-chave para a compreensão de processos sociais. In: Antropologia em primeira mão [online]. Florianópolis (SC): $\mathrm{CFH}$; 2007 [acesso 2013 Nov 13]. Disponível em: http:// www.cfh.ufsc.br/ antropos/97.pdf

19. Ramos DM, Nascimento VG. A família como instituição moderna. Fractal: Rev Psicol. 2008; 20(2):461-72.

20. Gomes BR, Adorno RCF. Tornar-se "noia": trajetória e sofrimento social nos "usos de crack" no centro de São Paulo. Rev Etnográfica. 2011; 15(3):569-86.

21. Cruz VD, Oliveira MM, Pinho LB, Coimbra VCC, Kantorski LP, Oliveira JF. Condições sociodemográficas e padrões de consumo de crack entre mulheres. Texto Contexto Enferm [online]. 2014 [acesso 2014 Mar 06]; 23(3):1068-76. Disponível em: http://www.scielo.br/pdf/tce/v23n4/ pt_0104-0707-tce-23-04-01068.pdf 